\title{
The Role of Situational and Individual Factors on the Premature Sign-Offs of Audit Procedures
}

\author{
Cakti Dito Angkoso ${ }^{1)}$, Bambang Subroto ${ }^{2)}$, Sutrisno ${ }^{3)}$ \\ ${ }^{1}$ Postgraduate Program, Faculty of Economic and Business, University of Brawijaya. Malang-Indonesia \\ ${ }^{2}$ Faculty of Economic and Business, University of Brawijaya. Malang-Indonesia \\ ${ }^{3}$ Faculty of Economic and Business, University of Brawijaya. Malang-Indonesia
}

\begin{abstract}
This research aims to examine the role of situational and individual factors on premature sign offs behavior during the work of audit procedure at CPA (Certified Public Accountant) firms in Surabaya. The situational factors examined in this research consist of time pressure, audit risk, review procedure, and quality control; meanwhile, the individual factors observed in this research are organizational commitment and turnover intention. The sample of this research is auditors at CPA firms in Surabaya with 186 auditors sample as the predetermined sample who are selected by using random sampling technique. The research instrument is questionnaire. The data of this research is analyzed by using Friedman test and logistic regression analysis. The analysis result demonstrates that there is a priority sequence of the signed-offs audit procedures. The logistic regression test demonstrates that situational factor and individual factor influence premature sign-offs of the audit procedure. This research also finds high time pressure, audit risk, and turnover intention which is directly experienced by the auditor caused premature sign-offs. On the contrary, tight review procedure and quality control as well as high organizational commitment of an auditor can prevent premature sign-offs of the audit procedure.
\end{abstract}

Keywords: Premature sign-offs audit procedures, audit risk, time pressure, review procedure and quality control, organizational commitments, and turnover intention

\section{Introduction}

Auditor is someone who is responsible for planning and implementing audit process to attain sufficient credence regarding the financial statement which is free from error and wrong presented material to state unqualified opinion of the fairness of the financial statement. Regarding the fairness of an organization's financial statement, auditors should have a rounded evaluation on the audit evidences (record evidences) based on the audit procedure that is implemented. A good and meticulous audit will ease auditors and CPA firms in arranging qualified audit report (Malone and Roberts, 1996).

However, the recent condition is far different from the previous research's findings. The research demonstrates the existence of dysfunctional audit behaviors such as misuse, manipulation, and fraud on the auditing standards due to premature sign-offs behaviors. Thus, the emergence of those kinds of behavior becomes a threat that may decrease audit quality.

A decrease on the quality of audit in Indonesia can be proven from some cases of audit failures and the number of sanctions determination from Minister of Finance to the CPA and CPA firms. Reflecting on the cases that took place in 2009, Minister of Finance froze the license of 3 Public Accountants: Drs. Basyiruddin Nur, Hans Burhanuddin Makarao and Drs. Dadi Muchidin, and 5 CPA firms: Drs Dadi Muchidin, Matias Zakaria, Drs. Soejono, Drs. Abdul Azis and Drs. M. Isjwara (Infobanknews, 2009). It happened because those CPA and CPA firms have not yet fully complied the law of Auditing Standards in the implementation of audit on the audited organization's financial statement. This premature sign-offs behavior in the audit procedure implementation is perceived to be a significant matter that influences the quality of external auditor's audit report. Next, this condition will affect the opinion of the auditor which becomes insufficient to observe the fairness of the audited financial statement.

\subsection{Statement of the Problem}

Premature sign-offs behavior occurs in every auditor's action during auditing procedures implementation by ignoring one or some parts of audit process. Premature sign-offs behavior became a crucial focus of attention. Coram et.al (2004) stated that the punishment for the auditor who conducts this behavior will be very severe; even, it ends up on firing. In Indonesia, since the Undang-Undang Akuntan Publik (Law of Public Accountant) was issued, premature sign-offs behavior will be punished and sanctioned for criminal action of the auditor; also, it has administrative sanction that comes before the cancelation of practice license as an auditor. It is based on the criminal act rules for auditor or public accountant in Undang-Undang Akuntan Publik No. 5 2011, article 55a; when an auditor or public accountant purposely erase or eliminate data or 
records on worksheet and when and auditor or public accountant does not arrange worksheet related to particular audit service that auditor delivers.

In the code of conducts for Public Accountant, premature sign-offs behavior done by auditors during auditing process is considered unethical, since the behavior is not relevant with the applicable law and breaks the existing audit standard as well as CPA firms policy. At the end, this kind of inappropriate practice will result in invalid and not reliable information which is presented by the auditor; further, it will decrease the quality of the audited financial statement.

According to Rodhe's (1978) research result, it revealed that more than 50\% of the AICPA members had made sign-offs behavior during the auditing procedures. In Indonesia, two researches by Heriningsih (2002) and Weningtyas et.al. (2007) demonstrated that 56\% and 13\% of the sample of each research respectively tended to make premature sign-offs behavior. The findings concluded the reasons of why those auditors made premature sign-offs behavior such as: the tight due date of audit report, poor understanding on audit procedure, unavailable materials in the implementation of audit procedure, perceiving that audit procedure is not important, boredom factor of the auditor, and limited term of determined audit time range (Rhode, 1978; Alderman and Deitrick, 1982). As those reasons emerged, it explained that premature sign-offs behavior can occur due to the internal factors and external factors.

Donnelly et al., (2003) demonstrate that an auditor with external locus of control, organizational commitment, and turnover intention positively correlates to the acceptance level on the dysfunctional behavior of premature sign-offs. Prior researchers, Alderman and Deitrick (1982) stated that time pressure has significant effect on audit performance. From their result, it is found that the priority sequence of audit procedure will be stopped in analytical procedure, internal audit's job review, and lower level auditor's job supervision. The different result from Malone and Roberts (1996) demonstrated that time pressure as an external factor does not influence on the emergence of premature sign-offs behavior. Further, it was also found that turnover intention as internal factor also does not have any significant effect on premature sign-offs.

In Indonesia, Heriningsih (2002) found that there is a role of time pressure and audit risk on premature sign-offs behavior. Further, Indarto (2011) in his research concluded that there is a positive significant role of time pressure and audit risk on premature sign-offs. Besides, there is a negative role of review procedure and quality control of KAP, organizational commitment, professional commitment, as well as procedure and ethical awareness on premature sign-offs behavior.

Different from the research result conducted by Weningtyas et.al.(2007), the research found negative role of review procedure, quality control, and available materials. Yet, Weningtyas et.al. (2007) found that time pressure and audit risk positively influences premature sign-offs behavior. The research result based on priority sequence found that an understanding on client's business is an audit procedure that is often ignored; meanwhile, physical verification is an audit procedure which is seldom ignored.

Another research by Maryanti (2005) which examined by using individual's characteristics approach found that performance, turnover intention, and organizational commitment have positive influence on premature sign-offs behavior. Different from the research conducted by Wahyudi et.al. (2011), the research does not find any significant role of time pressure, audit risk, review procedure, quality control, and organizational commitment on premature sign-offs behavior.

\subsection{Research Motivation}

The gap among those former research results regarding the premature sign-offs behavior which occurs due to the internal and external factors faced by the auditor in implementing audit program encourages the author to conduct this research. This research is urgent to be conducted due to the vulnerability of CPA and CPA firms to do premature sign-offs behavior; in addition, there is also an increase demand among the users of published financial statement for professional auditor to attain trusted and quality audit report.

\subsection{Research Contribution}

This research provides some contributions from the theoretical, practical, and policy perspectives. Theoretically, the result of this research presents empirical proofs regarding the role of auditor's situational factor and individual factor on premature sign-offs behavior. Practically, this research delivers some benefits for Managing Partner (MP) as the highest leader in CPA firms to re-evaluate every policy and manage the CPA firms Quality Control System whether it already runs well and effectively. From the policy perspective, this research supports UU Akuntan Publik No.5 2011 which provides criminal sanction and administrative sanction for CPA and CPA firms as they do not establish processes based on the standard procedures. 


\subsection{Attribution Theory}

\section{Literature Review}

Attribution theory tells about how an individual makes a decision regarding other individuals. Individual arranges attribution when he or she feels and describes others' behavior as well as tries to reveal knowledge related to why they behave in such a way. Attribution theory will provide a knowledge regarding the process so that we know the causes and the motives of an individual's behavior. According to Kelley (1972) this theory is directed to develop the explanation related to how an individual perceives another variously depending on the meaning that the individual attributes to particular behavior.

According to Robbin (2003), there are two focuses to look for the cause of particular event, including the internal side of someone (dispositional attributions) and from the external side of someone (situational attributions). Dispositional attributions tend to refer to the behavioral aspect of individual; it is something that already exists in an individual. Next, situational attributions refer more to the environment which influences someone's behavior. Attribution theory evaluates what have caused an auditor to do premature sign-offs behavior based on those factors.

\subsection{Premature Sign-Offs}

Premature sign-offs is an action of an auditor for not implementing or ignoring one or some required audit procedures. Auditor refuses to record all of the auditor procedures that he/she has accomplished entirely (Alderman and Deitrick, 1982). This behavior causes a decrease on the quality of audit issued by CPA firms. It is due to the audit evidence that is supposed to be collected through a series of audit procedures is not properly attained and not sufficient. This condition influences the opinion issued by the auditor to which becomes not valid to assess the fairness of audited financial statement. Premature sign-offs can encourage an auditor to collect insufficient evidence as the foundation of opinion issue (Kelley and Margheim, 1990).

\subsection{Research Conceptual Framework}

\section{Conceptual Framework And Hypothesis}

The conceptual framework built in this research is described in one scheme of conceptual thinking which is expected to be able to describe the research that is going to be conducted. The research addresses the role of situational and individual factors on premature sign-offs behavior. The conceptual framework of this research is illustrated in Figure 1.

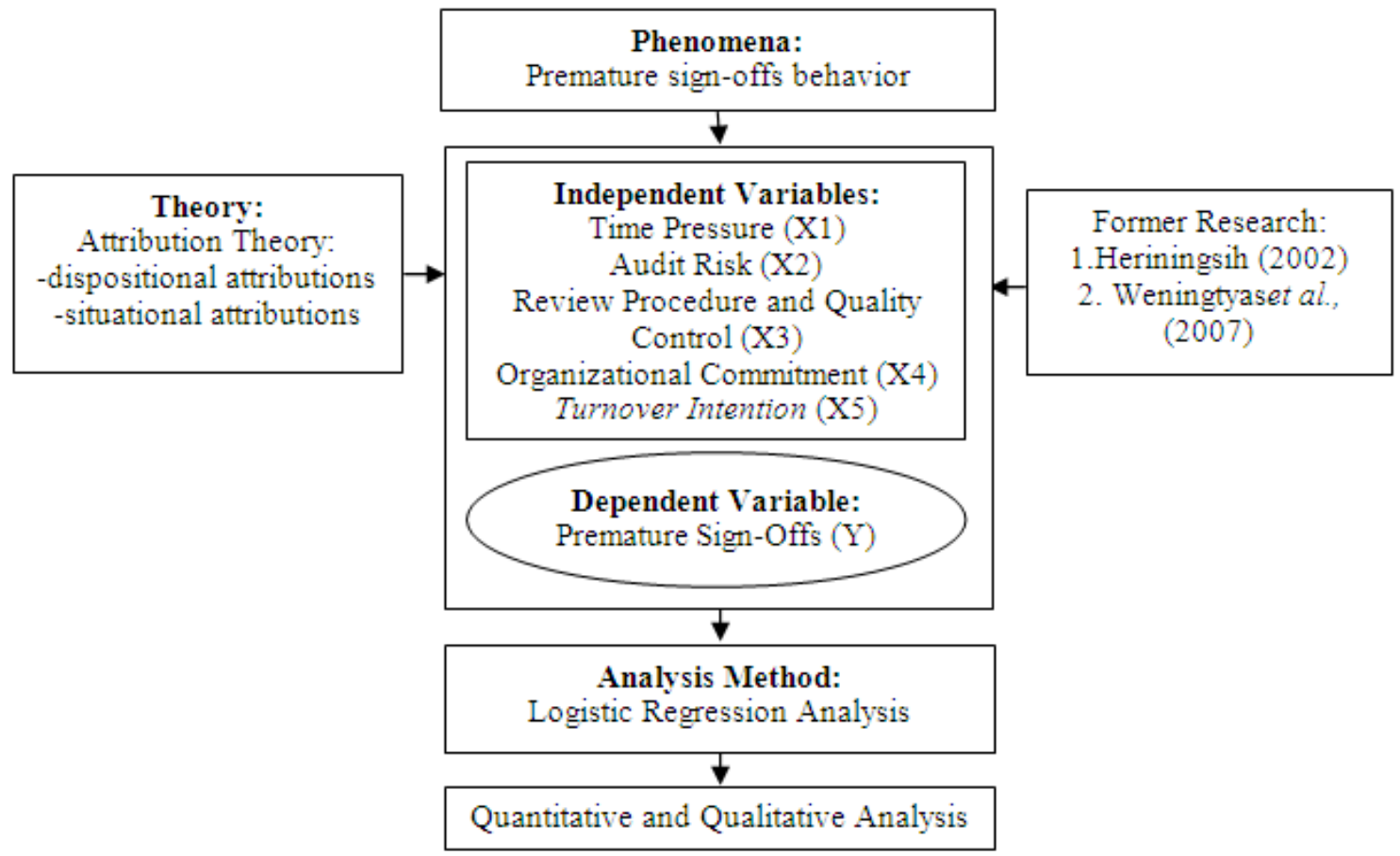

Figure 1. Research Conceptual Framework

\subsection{Research Conceptual Framework}

Based on the conceptual framework described in Figure 1, it leads to the hypotheses model of this research below: 


\subsubsection{There is a Priority sequence to Sign-Off the Audit Procedure}

Job quality of an auditor is reflected on the meticulousness of the auditor to run the audit procedures which are listed in audit program. Auditor uses audit procedure as a supervision tool for inexperienced audit assistant who will conduct audit.

Alderman and Deitrick (1982) found the part of audit procedures that are often signed-off prematurely such as review stage, client's internal control system test which mostly happens at partner side. Next, Weningtyas et.al. (2007) found that knowledge on client's business procedure is the most often ignored procedure. Further, Heriningsih (2002) found that the audit procedure that is mostly signed-off prematurely is sample number reduction.

Based on the prior research findings that when an auditor ignores audit procedure, he/she tends to do premature sign-offs which is less risky among the required audit procedures; thus, it leads to the priority sequence regarding the audit procedure that is signed-off. Based on the sequence above, it leads to the following hypothesis:

\section{$H_{1}$ : There is a priority sequence of the audit procedure that is signed-off}

\subsubsection{The Role of Time Pressure on Premature Sign-Offs}

Time pressure is a pressure to accomplish the audit tasks based on the targeted time. In attribution theory, time pressure is caused by external factor (situational attributions); the external factor refers to the environment which influences the target time to accomplish field work.

Rhode (1978) indicated that time pressure and premature sign-offs only occur on an auditor who works at small CPA firms. Yet, Alderman and Deitrick (1982) indicated that an auditor who works at big CPA firms also experiences time pressure during the audit process. The time pressure, Alderman and Deitrick (1982) said, encourages auditor to do premature sign-offs. Coram et.al. (2004) demonstrated that an auditor who works at large CPA firms experience high budget and time pressures; thus, this condition makes auditor reduce their quality of audit during the implementation of audit procedure. In Indonesia, Weningtyas et.al (2007) found that time pressure positively influences premature sign-offs.

When an auditor is demanded to accomplish the required audit procedure as quick as possible based on the time due as well as required to make a report punctually, it causes a higher time pressure faced by the auditor during field work. Therefore, the intention of an auditor to do premature sign-offs is even higher as well. Based on this description, the researchers propose the following hypothesis:

$\mathrm{H}_{2}$ : There is a positive role of time pressure on premature sign-offs.

\subsubsection{The Role of Audit Risk on Premature Sign-Offs}

In this research, audit risk means detection risk. This risk shows the uncertainty condition faced by the auditor as the proofs gathered by the auditor cannot detect the material misstatement. In attribution theory, audit risk is due to external factors (situational attributions) since the external causes refer to the influencing condition such as the uncertainty faced by the auditor during the collection of audit evidence and not be able to detect material misstatement.

High detection risk determination of the auditor may be due to auditor's assurance that without arranging particular audit procedure, the issued audit opinion is still not wrong (Weningtyas et al., 2007). The research result conducted by Weningtyas et al., (2007) demonstrated that detection risk has positive role on premature sign-offs.

Therefore, when auditor determines high low-risk detection, it means that the auditor want the entire audit evidences that are collected can detect the material misstatement. By this condition, the audit evidence that is needed will be greater and the audit procedure will be wider as well. Next, when the audit risk is high, then the audit procedure becomes lesser; also, the collected audit evidence will be lesser as well. Therefore, the possibility for the auditor to practice premature sign-offs becomes higher. Based on the description here, it leads to the following hypothesis:

\section{$H_{3}$ : There is positive role of audit risk on premature sign-offs.}

\subsubsection{The Role of Review Procedure and Quality Control on Premature Sign-Offs}

The implementation of good review procedure and good quality control will improve the possibility ofdetecting dysfunctional behavior during audit such as premature sign-off practice. Waggoner and Cashell (1991) stated that review procedure is much needed in particular CPA firms to control the possibility of premature sign-off practice taken by its auditors. In attribution theory, review procedure and quality control happens in external side of an individual (situational attributions) as the external causes more refers to review and control system that is applied by the CPA firms where the auditor is working.

Weningtyas et al., (2007) stated that good review procedure and good quality control will improve the possibility of detecting auditor's dysfunctional behavior such as premature sign-off practice. Indarto (2011) 
concluded that review procedure and quality control applicable at KAP negatively influence premature sign-off. The research result supports the research conducted by Weningtyas et.al. (2007) as it found that review procedure and quality control negatively influence premature sign-off.

Therefore, the implementation of high review procedure and effective quality control will ease the effort to detect premature sign-off; on the contrary, low quality implementation of review procedure and quality control will result in greater possibility of the auditor to do premature sign-off. Based on the description above, the researcher proposes the following hypothesis:

\section{$\mathrm{H}_{4}$ : There is negative role of review procedure and quality control on premature sign-off}

\subsubsection{The Role of Organizational Commitment on Premature Sign-Offs}

Mowday, Porter and Dubin (1979) identified commitment as a relative strength of individual identification toward particular organization and the involvement of particular organization which is characterized by three psychological factors: (1) strong willingness to stay as the member of particular organization, (2) willingness to make the best effort for the organization, (3) trust and acceptance on the values and objectives of the organization. In attribution theory, organizational commitment is affected by behavior and individual motives. Dispositional attributions (from the internal side) refer more to self-perception with how to place him on an organization to where he/she works. Organizational commitment of the auditor also can influence the difference on the level of acceptance of the premature sign-offs. It is because an auditor who has high organizational commitment tends to refuse premature sign-offs.

Maryanti (2005) found that performance, turnover intention, and organizational have positive role. Meanwhile, Indarto (2011) concluded that organizational commitment on auditor organization, professional commitment of the auditor, procedure and ethical awareness, significantly and negatively influence premature sign-off.

Therefore, an auditor who has high organizational commitment will work based on the required standards even though at under high pressure situation. Auditor with high organizational commitment will tend to avoid to get involved in premature sign-offs. Based on the description above, the researcher proposes the following hypothesis:

$\mathrm{H}_{5}: \quad$ There is a negative role of organizational commitment on premature sign-offs.

\subsubsection{The Role of Turnover Intention on Premature Sign-Offs}

Robbins (2003) defined turnover intention as an individual's willingness with full awareness to leave the organization to where he/she works. In attribution theory, turnover intention is affected by behavior and individual motives. The internal cause of turnover intention (namely dispositional attribution) refers to motivation from the internal side of individual on the willingness to stay or still work at the organization where he/she is working now.

Research conducted by Donnelly et al., (2003) concluded that there is a positive role of the high turnover intention on premature sign-offs as the dysfunctional audit behavior. In Indonesia, a research conducted by Maryanti (2005) indicated that turnover intention positively influences the emergence of premature sign-offs behavior.

An auditor who has a turnover intention to leave CPA firms aims to look for another job so that the auditor does not worry if gets a sanction from the actions auditor conducts. Thus, this condition makes the auditor tend to get involved in premature sign-offs behavior. Based on this description, it leads to the following hypothesis:

$\mathbf{H}_{6}$ : There is a positive role of turnover intention on premature sign-offs.

\subsection{Population, Sample, and Sampling Technique}

\section{Research Method}

The population of this research is the auditors who work at CPA firms in Surabaya. The total population is 613 auditors from $48 \mathrm{CPA}$ firms. The analysis unit is all of the auditors ranging from junior level to partner level.

The predetermined sample of this research is 242 auditors who work at CPA firms Surabaya. The number is defined based on Slovin's sampling technique. Slovin's sampling is utilized based on the population of the auditors in CPA firms Surabaya as the exact number is known. This research utilizes random sampling technique by using random formula and index on Microsoft Office Excel. 


\subsection{Operational Definition of the Research Variables \\ 4.2.1 Independent Variables}

\subsubsection{Time Pressure}

Time pressure is a condition to where an auditor gets a pressure or forced to accomplish tasks as quick as possible based on the predetermined time budget. Time pressure variable is measured by using 5 question items as its indicators which is developed by Heriningsih (2002). Time pressure indicator is measured through interval scale by using 5 points of Likert's scale ranging from 1 "Never" to 5 "Almost Always."

\subsubsection{Audit Risk}

Audit risk shows the uncertainty condition faced by the auditor as the proofs gathered by the auditor cannot detect the material misstatement. Audit risk variable is measured by using an instrument developed by Heriningsih (2002). The variable of this instrument consists of 3 question items as its indicators. The audit risk indicator is measured through interval scale by using 5 points of Likert's scale ranging from 1 "Strongly Disagree" to 5 "Strongly Agree."

\subsubsection{Review Procedure and Quality Control}

Review procedure and Quality Control is much needed in particular CPA firms to control the possibility of premature sign-off practice taken by its auditors. Review procedure and quality control of audit are measured using the instruments developed by Malone and Roberts (1996). The variable of this instrument consists of 5 question items as its indicators. Review procedures and quality control indicator is measured through interval scale by using 5 points of Likert's scale ranging from 1 "Strongly Disagree" to 5 "Strongly Agree."

\subsubsection{Organizational Commitment}

Organizational commitment as a relative strength of individual identification toward particular organization and the involvement of particular organization. Organizational commitment is measured by using the instrument developed by Mowday et al., (1979). The variable of this instrument consists of 9 question items as its indicators. Organizational commitment indicator is measured through interval scale by using 5 points of Likert's scale ranging from 1 "Strongly Disagree" to 5 "Strongly Agree."

\subsubsection{Turnover Intention}

Mobley et al., (1979) stated that turnover intention of an individual can contribute to the explanation regarding the perception and evaluation on his or her job. Turnover intention is measured by using the instrument developed by Mobley et al., (1979). The variable of this instrument consists of 3 question items as its indicators. Organizational commitment indicator is measured through interval scale by using 5 points of Likert's scale ranging from 1 "Strongly Disagree" to 5 "Strongly Agree."

\subsubsection{Dependent Variables}

\subsubsection{Premature Sign-Offs}

Premature sign-offs behavior occurs in every action of an auditor during auditing procedures implementation by ignoring one or some parts of audit process. This variable is measured by using the instrument proposed by Raghunathan (1991) which is then developed by Heriningsih (2002). Heriningsih (2002) modified the 10 question items of audit procedure to adjust with the condition in Indonesia which has the possibility of premature sign-offs behavior to occur. Premature sign-offs indicator is measured through ordinal scale by using 5 points of Likert's scale ranging from 1 "Never" to 5 "Almost Always."

\subsection{Data Analysis Technique}

Hypothesis 1 is examined by using Friedman non-parametric statistical test. The test is intended to know the priority rank of premature sign-offs. Next, from Hypothesis 2 until Hypothesis 6, those are examined to know the role of time pressure, audit risk, review procedure and quality control, organizational commitment, and turnover intention toward premature sign-offs. Hypothesis 2 to until Hypothesis 6 testing are conducted by using logistic regression analysis.

The logistic regression model is then transformed into probabilities with logit function. Further, it uses maximum likelihood to examine hypothesis of this research by using logit function. Next, it is analyzed by using maximum likelihood to examine the hypothesis of this research by the following formula:

$$
\begin{array}{ll}
\text { In } & \frac{P_{i}}{1-P_{i}}=\alpha+\beta_{1} X_{1}+\beta_{2} X_{2}+\beta_{3} X_{3}+\beta_{4} X_{4}+\beta_{5} X_{5} \\
P_{i} & : \text { The probability of the premature sign-offs occurrence }
\end{array}
$$




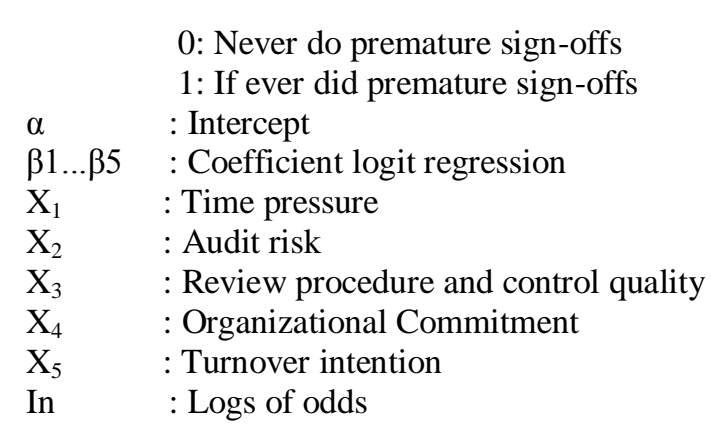

\subsection{General Description of This Research}

\section{Data Analysis}

This research was conducted during $11^{\text {th }}$ of July 2014 until $25^{\text {th }}$ July 2014. This research was administered by sending 242 questionnaires (both through email and direct delivery) to the auditors in several offices of CPA firms in Surabaya. Later, there are 186 usable questionnaires of this research among 242 distributed questionnaires.

The high response rate of the questionnaire distribution emerged because the researcher directly delivered the questionnaires to the contact person of each CPA firms that has been determined as the research sample. Also, the time of questionnaire distribution was not during the due date of financial statement issues and audit interim period so that the auditors as the research respondents are enthusiastically willing to fulfill the distributed questionnaires. The calculation of the questionnaires that are distributed and returned during the research period is presented in Table 1 .

Table 1: Questionnaire Distribution and Return Summary

\begin{tabular}{lll}
\hline DESCRIPTION & AMOUNT & TOTAL \\
\hline Direct delivery & 228 & \\
Email delivery & 14 & 242 \\
Total questionnaire sent & & \\
Total questionnaire return and address match & $(21)$ & 221 \\
Total questionnaire received & & \\
Total questionnaire return & 14 & 190 \\
$-\quad \quad$ Email & 176 & 186 \\
- Direct delivery & & $78,51 \%$ \\
Total questionnaire return & $(4)$ & $76,9 \%$ \\
Questionnaire not fill/incomplete & & \\
Response rate & & \\
Usable response rate & & \\
\hline
\end{tabular}

\section{Source: Field Survey (2014)}

\subsection{Demographic Data Description}

\subsection{Respondent's Characteristics}

The number of respondents participated in this research is 186 respondents. Based on the gender, 118 of them $(63.44 \%)$ are man. From the education background, 162 of them $(87.10 \%)$ are bachelor graduates; while 115 of them $(61.83 \%)$ are not as registered accountants. The common position hold by the respondents is junior auditor as many as 126 respondents $(67.74 \%)$. The respondents whose the length of work is less than 2 years are 121 people $(65.05 \%)$. The full profile of the research respondents is presented in Table 2.

Table 2: Profile of Respondent

\begin{tabular}{lll}
\hline DESCRIPTION & TOTAL (PERSON) & PERCENTAGE \\
\hline Gender & & $63,44 \%$ \\
Male & 118 & $36,56 \%$ \\
Female & 68 & $0,54 \%$ \\
Education & 1 & $7,53 \%$ \\
S3 & 14 & $87,10 \%$ \\
S2 & 162 & $4,84 \%$ \\
S1 & 9 & $38,17 \%$ \\
D3 & & $61,83 \%$ \\
Accountant Registers & 71 & $67,74 \%$ \\
Yes & 115 & $11,29 \%$ \\
No & &
\end{tabular}




\begin{tabular}{lll} 
Manager & 21 & $11,29 \%$ \\
Partner & 13 & $6,99 \%$ \\
Experience & & $65,05 \%$ \\
$<2$ year & 121 & $18,82 \%$ \\
$2-5$ year & 35 & $16,13 \%$ \\
$>5$ year & 30 & $100 \%$ \\
\hline Total respondent & 186 & \\
\hline \hline
\end{tabular}

Source: Field Survey (2014)

\subsection{Non Response Bias, Reliability and Validity Test Results}

The non-response bias test result indicates that there is no bias on the response since all of the answers are received before the cutoff date; further, the email response through email and direct delivery do not have any bias response since t probability value $(0.120-0.910)$ is greater than 0.05 . The reliability and validity test result shows that all of the questions for premature sign-offs variables have Cronbach Alpha's score greater than 0.6. Furthermore, the total correlation value (0.561-0.952) is greater than it $r_{\text {table }}$ value $(0.144)$. This proves that the question items of the questionnaire are valid.

\subsection{Logit Regression Test Result}

The logit regression test result is needed to ensure that the logistic regression model used in this research is not bias and usable. The data of this research pass logit regression test, including multicollinearity, goodness of fit, overall model fit, and coefficient of logit regression tests.

\subsection{Hypothesis Test Result and Discussion}

The description of the respondent's answers on the question items regarding premature sign-offs behavior indicates that most of the auditors never do premature sign-offs behavior (56.99\% or 106 auditors); meanwhile, the rest $43.01 \%$ of them ( 80 auditors) made premature sign-offs behavior. Most of the premature sign-offs behavior is conducted by junior auditors (78 auditor or $97.5 \%)$. There are 77 auditors $(96.25 \%$ ) who ever made premature sign-offs behavior whose the length of work are less than 2 years.

\subsubsection{There is a priority sequence of the Signed-Offs Audit Procedure}

Based on the conducted research, the significance value implies that there is significant difference on the priority sequence of the audit procedure conducted by the auditor. The result indicates that when an auditor ignores audit procedure, then he/she tends to do premature sign-offs practice which results in difference priority sequence of the audit procedure that is stopped.

The result of this research confirms Alderman and Deitrick's (1982) and Raghunathan's (1991) research which demonstrated that there is a priority sequence of audit procedure hat is stopped. The finding of this research provides empirical evidence on the premature sign-off practice in Indonesia which previously has been observed as well by Heriningsih (2002) and Weningtyas et.al. (2007).

The result of this research shows that the procedure that is mostly stopped is internal audit consideration (see Table 3); whereas, the procedure that is the most rarely stopped is physical examination. The finding of this research shows different result due to different characteristics of the auditor behavior. Auditor who practices premature sign-off tends to carefully consider which procedure that should be stopped by making professional judgments.

Table 3: Priority sequence of the audit procedure sign-offs

\begin{tabular}{llll}
\hline NO & AUDIT PROCEDURES & MEAN RANK & PRIORITY \\
\hline 1 & Understanding the client business & 6,03 & 7 \\
2 & Understanding internal control & 4,90 & 4 \\
3 & Substantive testing & 5,27 & 5 \\
4 & Internal audit consideration & 3,27 & 1 \\
5 & Analytical procedures & 5,68 & 6 \\
6 & Confirmation & 7,09 & 8 \\
7 & Representation of management letter & 7,13 & 9 \\
8 & Compliance online testing & 3,30 & 2 \\
9 & Reduce to audit sampling & 4,60 & 3 \\
10 & Physical examination & 7,73 & 10 \\
\hline
\end{tabular}

Source: Field Survey (2014)

\subsubsection{The Role of Time Pressure on Premature Sign-Offs}

Based on the data analysis result, time pressure has coefficient and wald of 0.190 and 4.591 respectively with significance value of 0.032 . The significance value is less than 0.05 which implies that time pressure has positive role premature sign-offs. Next, this result confirms that greater time pressure perceived by 
an auditor during implementing audit procedure, the higher the tendency of the auditor to do premature signoffs.

This finding provides empirical evidence on attribution theory. High time pressure reflects that attribution perception come from the external side. Time pressure directly influences auditor behavior to practice premature sign-offs which comes from situation attribution factors.

Next, the result of this research also adds more empirical support on the findings of Alderman and Deitrick (1982), Coram et al., (2004), and Weningtyas et al., (2007). They found the positive role of time pressure with premature sign-off. Coram et.al. (2004) added that the size of CPA firms defines the time pressure; bigger CPA firms encourages auditor to reduce audit quality during the implementation of audit procedures.

In conclusion, the requirement to accomplish the audit job punctually based on the schedule causes a reduction on the audit's efficiency and effectiveness; thus, auditor practices a behavior which reduces the quality of audit directly through premature sign-offs practice.

\subsubsection{The Role of Audit Risk on Premature Sign-Offs}

Based on the data analysis result, time pressure has coefficient and wald of 0.246 and 3.941 respectively with significance value of 0.047 . The significance value is less than 0.05 which implies that audit risk has positive role premature sign-offs. Next, the research result indicates that greater predetermined audit risk in implementing audit procedure results in greater tendency of the auditor to practice premature sign-offs.

This finding provides empirical evidence on attribution theory. High audit risk reflects attribution assessment which comes from the external side of the auditor; however, those risks should be widely considered by the auditors regarding the implementation of audit procedures that should conduct.

Next, the result of this research also confirms theoretical support on Weningtyas et.al. (2007) research which mentioned that there is positive role of audit risk and premature sign-offs. However, this result does not support Heriningsih (2002) research which found that audit risk negatively influences premature sign-offs. Further, Heriningsih (2002) stated that an auditor who perceives that if the audit procedure is stopped when it has a high risk, the condition will prevent the auditor to reduce premature sign-offs behavior.

Therefore, the initial plan that has been determined regarding the audit risk becomes an important part of the audit process. If the risk determination is wrong, it will cause the implementation of audit process failed and reduce the quality of audit directly. Next, it needs strong professional judgments from the auditor to support the audit evidence as the foundation to issue audit opinion. Sufficient audit record or evidence should be measured as well regarding the determination of risk on audit detection.

\subsubsection{The Role of Review Procedure and Quality Control on Premature Sign-Offs}

Based on the data analysis result, review procedures and quality control has coefficient and wald of 0.221 and 7.543 respectively with significance value of 0.006 . The significance value is less than 0.05 which implies that review procedure and quality control has negative role premature sign-offs.

This finding provides empirical evidence on attribution theory. Tight review procedure and high quality control describe the attribution assessment which comes from the external side of the auditor. When an auditor perceives that the implementation of review procedure and quality control is effective in the firm, it will influence the auditor in conducting audit procedure.

The finding of this research supports prior research result from Weningtyas et al., (2007). This research also finds that an auditor who works at CPA firms with loose review procedure and low quality control tends to practice premature sign-offs.

Hence, the implementation of tight review procedure and quality control at CPA firms will directly influence the quality of the audit. The differences on the respondents' responses empirically prove that the size of CPA firms can influence the practice of premature sign-offs in the audit procedure since not all of the CPA firms has sufficient Quality Assurance Review to support the review process at CPA firms. The existence of quality assurance review will help CPA firms in ensuring that the professional audit standard has been properly implemented in the audit practice.

\subsubsection{The Role of Organizational Commitment on Premature Sign-Offs.}

Based on the data analysis result, organizational commitment has coefficient and wald of -0.217 and 20.264 respectively with significance value of 0.000 . The significance value is less than 0.05 which implies that organizational commitment has negative role premature sign-offs. The research result indicates that an auditor who has strong organizational commitment tends to avoid premature sign-offs behavior.

This finding provides empirical evidence on attribution theory. High organizational commitment describes the attribution assessment which comes from the internal side of the auditor. Auditor who perceives 
strong organizational commitment makes them more professional and highly considers professionalism ethics or code of conduct.

This research proves confirms Indarto (2011) research which concludes that auditor's organizational commitment negatively influences premature sign-offs behavior. Next, this research is contradictory to Maryanti (2005) research when Maryanti (2005) said that organizational commitment positively affects the behavior which reduces audit quality in the form of premature sign-offs practice. It is logical since an auditor who has high organizational commitment tend to be more loyal to the values and objectives of the organization.

Therefore, an auditor with high organizational commitment will work based on the applicable standards though he is under high pressure situation. Organizational commitment can be achieved if it is supported by his superintendent's behavior, culture, and organizational climate. If those three aspects have good values, an auditor will have high organizational commitment and does his best for his CPA firms.

\subsubsection{The Role of Turnover Intention Premature Sign-Offs}

Based on the data analysis result, time pressure has coefficient and wald of 0.358 and 25.796 respectively with significance value of 0.000 . The significance value is less than 0.05 which implies that turnover intention has positive role premature sign-offs. The result of this research indicates that higher turnover intention during practicing audit procedures results in greater chance of the auditor to practice premature signoffs.

This finding provides empirical evidence on attribution theory. High turnover intention demonstrates the attribution assessment which comes from the internal side of the auditor. As the auditor has an intention to resign (turnover intention) from the CPA firms, it will directly influence the auditor's behavior to practice premature sign-offs which comes from individual factor (dispositional attributions).

The acceptance of the research's hypothesis supports a research conducted by Donnelly et al., (2003) and Maryanti (2005) which find that the positive role of turnover intention of the practice of premature signoffs. The finding of this research is different from the research conducted by Malone and Roberts (1996) which stated that turnover intention does not have any role on premature sign-offs since an auditor who wants to resign from particular CPA firms still needs a recommendation from the existing CPA firms to obtain new job opportunities; thus, Malone and Roberts (1996) found that an auditor is not motivated to do premature sign-offs for achieving fair recommendation.

Therefore, an auditor who has turnover intention aims to find job other than the existing job that auditor has; thus, auditor is not afraid of being punished if the premature sign-offs behavior is revealed by the CPA firms. Auditor with high level of turnover intention occurs at junior level since junior auditor only focuses on gaining experience while they are working at the CPA firms. This behavior at last will influence the auditor to practice premature-sign offs.

\section{Conclusion}

Based on the research conducted, it shows that individual and situational factors influence premature sign-offs. High time pressure and audit risk that is faced directly by the auditor during the implementation of audit will encourage the occurrence of premature sign-offs; yet, tight and effective review and quality assurance conducted by CPA firms will reduce the possibility of the premature sign-offs to occur. Next, the high level of turnover intention will urge premature sign-offs; thus, it needs strong organizational commitment of the auditor to reduce or even eradicate the dysfunctional behavior like premature sign-offs.

This research indicates that $43.01 \%$ of the auditor is at least did premature sign-offs once. The result proves that premature sign-offs causes the a change sequence of priority among the audit procedures that should be stopped or ignored. The priority sequences for audit procedure that mostly stopped in this research are internal audit consideration and compliance test; meanwhile, the audit procedures that are rarely stopped are physical examination and management letter.

Next, specifically, most of the premature sign-off practice is conducted by junior auditor whom the length of work is less than two years. It is due to the junior auditors do not have sufficient experience and proper supervision from their superiors; thus, junior auditors are not quite qualified to issue strong professional opinion when they are making their audit procedure.

This research brings an implication on behavioral audit such as theoretical implication. Attribution theory provides more empirical support to reveal the factors which influence the occurrence of premature signoffs.

\section{Limitation}

However, this research also has some limitations. This research still uses Auditing Standards (in Indonesia: Standar Profesional Akuntan Publik-SPAP) 2001, since Auditing Standards based ISA is effectively implemented in Indonesia on $1^{\text {st }}$ of January 2013 which is applicable for audit report per $31^{\text {st }}$ of December 2013 
for issuers; and $1^{\text {st }}$ of January 2014 which is applicable for audit report per $31^{\text {st }}$ of December 2014 for nonissuers.

\section{Suggestion}

Based on the limitations of this research, there are some suggestions for further research to refer to International Standards on Auditing (ISA) as it is applicable since $1^{\text {st }}$ of January 2014; it may also refer to Independent Audit Report on $31^{\text {st }}$ of December 2014. By this date, all of the issuers and non issuers in Indonesia should entity the applicable standards. Further, the factors which influence premature sign-offs practice can be re-observed by using ISA auditing standards.

\section{References}

[1] Republik Indonesia. 2011. Undang-Undang No. 5 tahun 2011 tentang Akuntan Publik. Lembaran Negara RI tahun 2011 No. 51. Jakarta.

[2] Alderman, C.W., and Deitrick, J.W. 1982. Auditor's Perceptions of Time Budget Pressure and Premature Sign-0ffs: A Replication and Extension. Auditing: A Journal of Practice and Theory, 1 (2): 54-68.

[3] Arens, A.A., Elder, R.J., and Beasley, M.S. 2006. Auditing and Assurance Services. Edisi Kedua belas. Erlangga. Jakarta. h.36-55.

[4] Arens, A.A., Elder, R.J., Beasley, M.S., dan Jusuf, A.A 2011. Jasa Audit dan Assurance - Pendekatan terpadu (Adaptasi Indonesia). Salemba Empat. Jakarta. h. 48-280.

[5] Arikunto, S. 2007. Prosedur Penelitian Suatu Pendekatan Praktik. PT. Rineka Aksara. Jakarta. h.165-167.

[6] Boynton, W.C., Johnson, R.N., and Kell, G.W. 2003. Modern Auditing Jilid 1 Edisi Ketujuh (Alih Bahasa Rajoe, P.A., Gania, G., dan Budi, I.S), Erlangga. Jakarta. h. 12-15.

[7] Coram, P., Juliana, N.J., and Woodliff, D. 2003. A Survey of Time Budget Pressure and Reduced Audit Quality Among Australian Auditors. Australian Accounting Review, 13 (1): 38-45.

-----, and -----, 2004. The Effect of Risk of Misstatement on the Propensity to Comit Reduced Audit Quality Act under Time Budget Pressure, Auditing: A Journal of Practice and Theory, 23 (2): 159-167.

[8] Donnely, P.D., Quirin J.J., and O'Bryan D. 2003. Auditor Acceptance of Dysfunctional Audit Behavior: An Explanatory Model Using Auditor's Personal Characteristics'. Behavioral Research In Accounting, 15 (1): 87-110.

[9] Douglas, A., Wiliam, G.M., and Samuel, A.W. 2005. Statistical Techniques in Business and Economics. The McGraw-Hill. Inc. USA. h.118-137.

[10] Fleming, M.K. 1980. Budgeting Practices in Large CPA Firms. The Journal of Accountancy. May: 55-62.

[11] Ghozali, I. 2011. Aplikasi Analisis Multivariate dengan Program SPSS, Edisi Kelima, Badan Penerbit Universitas Diponegoro. Semarang. h.333-356.

[12] Gujarati, D. 2003. Ekonometrika Dasar. Erlangga. Jakarta. h.583-597

[13] Hair, J.F., Anderson, R.E., Tatham, R.L., and Black, W.C. 1995. Multivariate Analysis. 5 Edition. The McGraw-Hill. USA. h. 160188.

[14] Heriningsih, S. 2002. Penghentian Prematur Atas Prosedur Audit: Sebuah Studi Empiris Pada Kantor Akuntan Publik. Jurnal Wahana, 2 (1): 111-122.

[15] Hosmer, D.W., and Lemeshow. 1989. Applied Logistic Regression. New York: Jhon Willey and Sons. USA. h. 52-70.

[16] Ikatan Akuntan Publik Indonesia, 2011, Standar Profesional Akuntan Publik, IAPI. Penerbit Salemba Empat. Jakarta.

[17] Ikatan Akuntan Publik Indonesia-KAP. 2013. Direktori Kantor Akuntan Publik dan Akuntan Publik. Jakarta. IAPI-KAP.

[18] Indarto, S.L. 2011. Analisis Faktor-Faktor yang Mempengaruhi Penghentian Prematur atas Prosedur Audit. Jurnal Dinamika Sosial Ekonomi, 7 (2): 197-210.

[19] Infobanknews, 2009. Kasus pembekuan izin terhadap AP dan KAP. http://www.infobanknews.com/2009/09/menkeu-bekukan-izin8-akuntan-publik-dan-kantor-akuntan-publik/. Diakses 7 Juli 2014.

[20] Hartono, J. 2004. Metode Penelitian Bisnis: Salah Kaprah dan Pengalaman- Pengalaman. Yogyakarta: BPFE. h.119-125.

[21] Irawati, Y., Petronila, T.A., dan Mukhlasin. 2005. Hubungan Karakteristik Personal Auditor Terhadap Tingkat Penerimaan Penyimpangan Perilaku Dalam Audit. Simposium Nasional Akuntansi (SNA) VIII. Solo.

[22] Jones, T.M. 1991. Ethical Decision Making by Individual in Organization: An Issue- Contingent Model. Academic of Management Review, 16 (2): 366-395.

[23] Kelley, H.H. 1972. Attribution in social interaction. Attribution: Perceiving the causes of behavior. Morristown, NJ.General Learning Press: 1-26.

[24] Kelley, T., and Margheim, L. 1990. The Impact of Time Budget Pressure, Personality and Leadership Variabel on Dysfunctional Behavior. Auditing: A Journal of Practice and Theory. 9 (2): 21-41.

[25] Malone, C.F., and Robert, R.W. 1996. Factors Associated With the Incidence of Reduced Audit Quality Behavior. Auditing: A Journal of Practice and Theory. 15 (2): 49-64.

[26] Margheim, L., and Pany K. 1986. Quality Control, Premature Sign-off and Underreporting of Time: Some Empirical Findings. Auditing: A Journal of Practice and Theory, 5 (2): 50-63.

[27] Maryanti, P. 2005. Analisis Penerimaan Auditor Atas Dysfungctional Audit Behavior: Pendekatan Karakteristik Individual Auditor (Studi Empiris Pada Kantor Akuntan Publik di Jawa). Jurnal Manajemen Akuntansi dan Sistem Informasi, 5 (2): 213-225.

[28] Messier, W.F. 2000. Auditing and Assurance Service. New York: McGraw-Hill. USA. h. 20-35.

[29] Mobley W.H., Griffeth R.W., Hand H.H., and Meglino B.M. 1979. Review and Conceptual Analysis of Employee Turnover Process. Psychological Bulletin. Ap. 1.

[30] Mowday. R., Porter, L., and Dublin. R. 1979. The measurement of organizational commitment. Journal of vocational behavior. 14 (1): 224-227.

[31] Raghunathan, B. 1991. Premature Signing-Off of Auditor Procedure an Analysis. Accounting Horizon. 5 (2): 71-79.

[32] Rhode, J.G. 1978. Survey on The Influence of Selected Aspects of The Auditor's Work Environment on Professional Performance of Certified Public Accountant. New York, NY: American Institute of Certified Public Accountants.

[33] Robbins, S.P. 2003. Organizational Behavior. New Jersey: Prentice - Hall. USA. h. 43-62.

[34] Sekaran, U. 2003. Research Methods For Business: Metodologi Penelitian untuk Bisnis. Salemba Empat. Jakarta. 76-78

[35] Setiawan, I. A., dan Ghozali, I. 2006. Akuntansi Keperilakuan: Konsep dan Kajian Empiris Perilaku Akuntan. Badan Penerbit Universitas Diponegoro. Semarang. h. 4-21. 
[36] Shapeero, M., Koh, H.C., and Killough, L.N. 2003. Underreporting and Premature Sign-off in Public Accounting. Managerial Auditing Journal. 18. (6/7): 478-489.

[37] Santoso, S. 2014. Statistik Multivariat Edisi Revisi. PT Elex Media Komputindo. Jakarta. 216-224.

[38] Siregar, S. 2013. Metode Penelitian Kuantitatif Dilengkapi Dengan Perbandingan Perhitungan Manual dan SPSS. Kencana Prenada Media Group. Jakarta. 33-34.

[39] Waggoner, J.B., and Cashell, J.D. 1991. The Impact of Time Pressure on Auditor's Performance. CPA Journal, 50 (1): $27-32$.

[40] Wahyudi, I., Lucyanda, J., dan Suhud. L.H. 2011. Praktik Penghentian Prematur atas Prosedur Audit. Media Riset Akuntansi, 1(2): $125-140$.

[41] Weningtyas, S., Setiawan D., dan Triatmoko, H. 2007. Penghentian Prematur atas Prosedur Audit. Jurnal Riset Akuntansi Indonesia, $10(1): 1-19$. 